Bahar I. Ismayilova

DOI: $10.25045 /$ jpit.v08.i2.09

Educational Institute of Azerbaijan, Baku, Azerbaijan

bahar_ismayilova@yahoo.com

\title{
INTELLECTUAL GAMES: THE CURRENT SITUATION, PROBLEMS AND PROSPECTS
}

The article explores the possibilities of introducing intellectual games in the educational process. The structure and measurement of the intellect, and the types and functions of intellectual games are analyzed. Some proposals concerning the integration of intellectual games into the educational process are put forward.

Keywords: the quality of education, motivation, knowledge assessment, self-assessment, educational intellectual games, computer games, crossword

\section{Introduction}

The twenty-first century is an era of the triumph of the intellect and intelligence and the rapid development of science and technology, especially computer technology. Therefore, the formation of the schoolchildren of this century as the young people mastering currently required knowledge, ability, skills and values that adapt to the rapidly changing conditions of the globalized world, who can sustainably develop these competencies, depends on some factors. These factors may include the establishment of the educational processes at the institutions, the organization of the educational environment and so forth. One of the main tasks of the modern educator is to teach student how to learn, i.e., the ability to acquire knowledge independently. The classes organized in accordance of the students' interests and needs, level of knowledge and potential activate the cognitive process, while, the diverse knowledge, skills and values, logical, critical and creative thinking of the learners are formed and developed due to the logical questions and research activities given by the teacher . Properly structured student-teacher and student-student, teacherstudent-parent relationships increase self-esteem of the learner and encourage him/her.

The use of information technology (IT) by the vast majority of schoolchildren and young people particularly for games and entertainment is one of the pressing problems of the modern era and has a variety of negative consequences. Students show enthusiasm to computer games more at computer classes, and unsatisfactory learning motivation of the students, their skills to read and comprehend, analyze and synthesize the theoretical materials and terms. The lack of activity of each student at the learning process and the low percentage of mastering the knowledge, as well as the problems related to the knowledge assessment concern everyone engaged in the educational process. The right choice of the methods and tools, work books used at the classes is of great importance for creating the challenging situations that stimulate cognitive activity, encouraging the students to learn, organizing knowledge mastering, maintaining $100 \%$ activeness of the students at the learning process, improving the reading comprehension and understanding level of the learners.

In the modern times, preparing students for life is another important issue. Moreover, shaping their capabilities such as problem solving, decision-making and so forth is also very vital. Using intellectual games in teaching and learning, as well as in the evaluation process (diagnostic, formative, summative) of each subject gives effective results as one of the main tools that lead to the comprehensive development of learners. In different periods, the key aspects of the impact of different types of games on separate sectors have been studied. In addition, different methods and techniques, educational intellectual games and tests for the formation and improvement of multilateral knowledge and skills of the learners, and for their evaluation through more accurate, objective and humane ways and means have been practiced [1-4]. The results provided by the special federal tests checking the intellectual abilities and skills of the American students during the college admission play an exceptional role. It measures the students' intellectual abilities, knowledge and skills on specific subjects and checks their logical and mathematical thinking skills, vocabulary and the skills to use it [5].

Using the experience of the developed countries, the Azerbaijani schools are also widely using 
the student self-assessment method. Self-assessment enables the students to identify and successfully achieve their goals. For example, solving or preparing the different levels of educational crosswords, rebuses and intellectual tests covering various topics and units are of only very few methods motivating each student in the course of the lesson and their objective assessment, providing the students' self-assessment, improvement and self-learning through the books and extra materials.

IT is improving day by day and rapidly developing in the horizontal and vertical directions. This implies new opportunities for its use for teaching purposes. The use of intellectual and educational computer games in the course of computer science, as well as all other the subjects, is of special interest for the exploration of various issues and may contribute to the formation and development of a new approach to IT among the young generation.

\section{Intelligence, intelligence measurement}

Intelligence (Latin intellectus - "feeling, understanding, comprehension") - is the quality of mind and refers to the ability to understand and successfully implement any problem as the result of the mental skills, logical thinking, analyzing and systemizing the information, defining their application, finding the relationship, laws and differences between the information, and so forth. American sociologist, professor L.Gottfredson defines the intellect as the general mental abilities and as one's capacity for logic, understanding, self-awareness, learning, emotional knowledge, planning, creativity, and problem solving. It can be more generally described as the ability to perceive information, and to retain it as knowledge to be applied towards adaptive behaviors within an environment or context [6].

Intellectual human - is an analytical-minded and has a highly developed intelligence dealing with the intellectual labor. The parameters that form the different properties of the human's intellectual system include:

-working memory capacity, forecasting ability, logical thinking;

- consciousness;

-memory.

Different approaches to the intellect structure are available. For example, the American psychologist J.P.Guilford defines the three key parameters of intellect: Content, Operations, and "product". The content may be figural, voice, symbolic, and semantic.

Operations are represented by cognition (perception), memory recording, divergent production, convergent production, and evaluation.

"Product" means the object units (guess the units or words), classes (distinguishing object species, classification), relations (links between the objects), systems (to determine the organization rules of several objects and sets); transformations (changing, converting and transferring the given material), implications (projections of the results in uncertain situations).

Each dimension includes independent and specific elements. Therefore, the qualities of the human mind (the talent describing the quality of mind) are separately measured and evaluated [10].

Intelligence Quotient (IQ) is determined by using special tests as a quantity indicator of the person's intellectual abilities. The first intelligence tests were designed in the nineteenth century by French psychologist Alfred Binet [10].

$\mathrm{IQ}=($ Intellect age / biological age $) \times 100($ William Stern and Alfred Binet $)[33]$.

Psychologist of the Jewish-Romanian origin, professor D.Wechsler calculates the IQ as follows [10]:

$$
I Q=100+\frac{15(x-\mu)}{\sigma}
$$

Here, $x$ - determined value (the number of scores); $\mu$ - mean for the age group; $\sigma$ - random value dispersion.

Currently, the most popular intelligence tests are Shternford-Binet, Wechsler Intelligence Scale for Children (WISC), Wechsler Adult Intelligence Scale (WAIS), Kaufman Assessment Battery for Children (Kaufman-ABC). Though H.Y.Izek's tests are popular, the tests by H.Wechler, C.Raven, R.Amthauer, and R.B.Kettel are considered to be more accurate. 


\section{Intellectual games, their types, functions}

The exploration of the multiple versions of the games, which are one of the first forms of activities of the human mind and cultural life, and the analysis of the information about the game theory and game classification allows us understanding its essence as a unique socio-cultural phenomenon and approaching to this from the philosophical, psychological and pedagogical, ethical and cultural aspects. Accompanying all the living beings throughout the life, this type of activity is an important means for children and young people for development, self-understanding, self-realization, exploring surroundings, experiencing, mastering certain knowledge, skills and habits, and life-skills, while for the elderly (playing with grandchildren, different games and solving crossword, etc.) it is increasing the live motivation and health. Games are also widely used in the educational process. The percentage of using the games is higher at preschool educational institutions and primary schools than at the VXI classes. Therefore, the lack of the games played at high school or their less percentage can be regarded as one of the reasons for the decline in the learning motivation of the students and consequently in the quality of education. There are many ideas about the importance of the game in the literature: "intellectual game is very important as weather and food, as it has a big impact on the formation of certain skills [11],“...the game played during the childhood leaves a deep impression on the brain rather than the true and real life" [12], "The intellectual game is such a "ladder" that the higher a human rise of human, the more creative features he/she earn; playing the games a human is achieving a completeness; a game is before the culture, it generates the culture itself; "Playingman" and "Creating man" have the same vital functions" [13 ] "... game is a significant foundation of human civilization" [14] "... a game is a life school and a method of self-education for children" [15], "A game is a "calculation" of the social relations, one of the leading forms of developing the mental functions, and a cognitive method of the children to understand the real world (the adult world)" [16], "A game is a luminosity and light of the serious instinct" [17], "A game is a functional activity accompanied as a source of pleasure" [18], "A game is an activity of the entertainment, leisure and sporting nature. It helps the creation of typical situations and finding practical solutions to the occupations [19].

The notion of intellectual game was first used by K.Groos. Groos notes that the intellectual game has a special "complementary" function in the life of the people engaged in physical labor. in the course of the game, a person experiences an intellectual and emotional compensation; the person involved in the intellectual games feels the senses, which are forgotten in the real life filled with failures, conflicts, stress..., such as the joy of realizing the intellectual potentials, the sense of team work, the sense of victory [16].

The results of the experiments held in Japan, the US, Israel and other countries show that the people engaged in the intellectual work feel themselves very young. Famous psychologists and educators identify that the immeasurable potential of the human brain is not fully used. The compound and intellectual game, which can not be managed by every person, attracts not only the young, but also the elderly. Even some aged people have demand for intellectual games very much [20]. Intellectual game - is an activity where thinking and memory are fully involved in. whereas the mental operations of the participants-players are focused on defining and understanding the submitted material. To make tentative decisions about the accuracy of the responses and solutions and about the logic of the given situation, the convergence (one direction search for only accurate response) and divergent (different direction search, for example, in the simplest case, brainstorming method) is the productive game [21]. There are different types of intellectual games:

- According to Purpose: interactive and competition nature; logical; dimensional combinatorial games.

- According to the number of participants: individual (4 photos 1 answer, millionaire and so on.); couples; group ("Brain Ring", "Who? Where? When?",etc.) games.

- According to activity:

- Things: table polygraph (monopoly); table with things (chess, dominoes); spatialdimensional games.

- Writing: crossword puzzle; Rebus; 
- quiz etc.

- computer games. These games are also classified according to the genre, the number of players and the interaction, content and platform. For example, logic games, strategy, simulator/manager, and so on.

- According to the content [22].

Computer games - a type of intellectual games is a computer program organizing the process of game with the game partners or where the computer acts as a partner itself. Computer games can be created based on movie and book and vice versa. Since 2011, computer games have been officially recognized as a separate type of art in the United States. Being improved and having a significant impact on society, these games have turned into the steady and consistent trend creating gaming conditions for other applied software in IT. For example, integration of the games from twodimensional into the three-dimensional games has stimulated the development of three-dimensional applications (Maya, 3D Max, Blender, AutoCad, ArchiCad etc.). This trend has led to the development of not only three-dimensional programs, but of all areas (voice, video, etc.) as a whole with great speed.

To use the intellectual games and computer games in the education system, the teacher should determine their place and role in the educational process, and be able to jointly use playing and learning elements. Different forms of tasks, such as models, sketches, written or oral instructions can be used during the game. Thus, the students get familiar with the different types of information, its transmission methods and forms of presentation. They are enthusiastically and easily involved in the game. The effectiveness and productivity of the game, first of all, depends on its systematic use, as well as on the inclusion of the didactic tasks to the game. The game technology has a certain content, story and characters and can partially or fully cover the course. The story of the game develops in accordance with the main content of the education and contributes to the support of the learning process and to the mastering a number of learning elements. Developing a common game technology that involves particular training unit and contains the separate game elements means solving the problem that is not easy, but a great benefit for each teacher. For this, the teachers, first of all, need to know the properties of educational games, and try to find out when the game could provide the maximum result.

According to C.A.Shmakov, the intellectual games perform the following functions [23]:

1. socialization;

2. international communication;

3. self-realization;

4. communicative;

5. diagnostic;

6. therapeutic;

7. correction;

8. entertainment;

9. psycho-training.

Reviewing the nature and functions of the game, it should be noted that the game, in general, is one of the basic needs of people, especially children. While, the content of the game varies depending on the environment the child is involved in and his/her social status. In order to apply the intellectual games in the educational process, the teacher should know their classification and the time of the maximum effect of each game, and etc. Proper games are also used in the spheres, such as education, health care, industry, military and so on. The table below provides the information about the games used in separate spheres.

The educational intellectual games were originally designed for the elderly and young people. Most of these games were simulating the different types of human activities, and therefore, enabled the players to explore a number of social, historical and economic processes. For example, the games, such as SimCity series and Caesar (1993-2006), allows the players leading the city, dealing with the management, social, practical and economic processes. Through the empire-building games, such as "Civilization" (1991-2005) and "Europa Universalis" (2000-2007) series, the players are virtually operating in historical, political, economic and military spheres. 
Table 1

The main aspects of the impact of different types games in separate sectors [3]

\begin{tabular}{|c|c|c|c|c|c|c|c|}
\hline & $\begin{array}{l}\text { Games for } \\
\text { Health }\end{array}$ & $\begin{array}{l}\text { Adver- } \\
\text { games }\end{array}$ & $\begin{array}{l}\text { Games for } \\
\text { training }\end{array}$ & $\begin{array}{c}\text { Games } \\
\text { for } \\
\text { education }\end{array}$ & $\begin{array}{l}\text { Games for } \\
\text { science and } \\
\text { research }\end{array}$ & Production & $\begin{array}{l}\text { Games as } \\
\text { work }\end{array}$ \\
\hline $\begin{array}{l}\text { Govern- } \\
\text { ment \& } \\
\text { NGO }\end{array}$ & $\begin{array}{c}\text { Public } \\
\text { Health } \\
\text { Education } \\
\text { and Mass } \\
\text { Casualty } \\
\text { Response } \\
\end{array}$ & $\begin{array}{l}\text { Political } \\
\text { games }\end{array}$ & $\begin{array}{c}\text { Employee } \\
\text { training }\end{array}$ & $\begin{array}{l}\text { Inform } \\
\text { Public }\end{array}$ & $\begin{array}{c}\text { Data } \\
\text { collection \& } \\
\text { planning }\end{array}$ & $\begin{array}{l}\text { Strategic } \\
\& \text { Policy } \\
\text { planning }\end{array}$ & $\begin{array}{l}\text { Public } \\
\text { diplomacy } \\
\text { \& Opinion } \\
\text { research }\end{array}$ \\
\hline Defense & $\begin{array}{l}\text { Rehabilitat } \\
\text { ion\& } \\
\text { wellness }\end{array}$ & $\begin{array}{l}\text { Recruitment } \\
\& \\
\text { propaganda }\end{array}$ & $\begin{array}{c}\text { Soldier/sup } \\
\text { port } \\
\text { training }\end{array}$ & $\begin{array}{l}\text { School } \\
\text { house } \\
\text { education }\end{array}$ & $\begin{array}{c}\text { War games / } \\
\text { planning }\end{array}$ & $\begin{array}{c}\text { War } \\
\text { planning / } \\
\text { weapons } \\
\text { research }\end{array}$ & $\begin{array}{l}\text { Command } \\
\& \text { control }\end{array}$ \\
\hline Healthcare & $\begin{array}{c}\text { Cyber } \\
\text { therapy / } \\
\text { exergaming }\end{array}$ & $\begin{array}{l}\text { Public health } \\
\text { policy \& } \\
\text { social } \\
\text { awareness } \\
\text { campaign }\end{array}$ & $\begin{array}{c}\text { Training } \\
\text { games for } \\
\text { health } \\
\text { professionals }\end{array}$ & \begin{tabular}{|} 
Games for \\
patient \\
education \\
and disease \\
manage- \\
ment
\end{tabular} & $\begin{array}{c}\text { Visualization } \\
\& \\
\text { epidemiology }\end{array}$ & $\begin{array}{c}\text { Biotech } \\
\text { manufac- } \\
\text { turing \& } \\
\text { design }\end{array}$ & $\begin{array}{l}\text { Public } \\
\text { health } \\
\text { response } \\
\text { planning \& } \\
\text { logistics }\end{array}$ \\
\hline $\begin{array}{l}\text { Marketing } \\
\& \text { commu- } \\
\text { nication }\end{array}$ & $\begin{array}{c}\text { Advertising } \\
\text { treatment }\end{array}$ & $\begin{array}{l}\text { Advertising, } \\
\text { marketing } \\
\text { with games, } \\
\text { product } \\
\text { placement }\end{array}$ & $\begin{array}{l}\text { Product } \\
\text { use }\end{array}$ & $\begin{array}{c}\text { Product } \\
\text { information }\end{array}$ & $\begin{array}{l}\text { Opinion } \\
\text { research }\end{array}$ & Machinima & $\begin{array}{l}\text { Opinion } \\
\text { research }\end{array}$ \\
\hline Education & $\begin{array}{l}\text { Inform } \\
\text { about } \\
\text { diseases/ } \\
\text { risks }\end{array}$ & $\begin{array}{l}\text { Social issue } \\
\text { games }\end{array}$ & $\begin{array}{c}\text { Train } \\
\text { teachers / } \\
\text { train } \\
\text { workforce } \\
\text { skills }\end{array}$ & Learning & $\begin{array}{l}\text { Computer } \\
\text { science \& } \\
\text { recruitment }\end{array}$ & $\begin{array}{c}\text { P2P learning } \\
\text { construc- } \\
\text { tivism } \\
\text { document- } \\
\text { tary }\end{array}$ & $\begin{array}{l}\text { Teaching } \\
\text { distance } \\
\text { learning }\end{array}$ \\
\hline Corporate & $\begin{array}{l}\text { Employee } \\
\text { health } \\
\text { information } \\
\text { \& wellness }\end{array}$ & $\begin{array}{c}\text { Customer } \\
\text { education \& } \\
\text { awareness }\end{array}$ & $\begin{array}{l}\text { Employee } \\
\text { training }\end{array}$ & $\begin{array}{l}\text { Continuing } \\
\text { education \& } \\
\text { certification }\end{array}$ & $\begin{array}{l}\text { Advertizing / } \\
\text { visualization }\end{array}$ & $\begin{array}{l}\text { Strategic } \\
\text { planning }\end{array}$ & $\begin{array}{l}\text { Command } \\
\& \text { control }\end{array}$ \\
\hline Industry & $\begin{array}{l}\text { Occupa- } \\
\text { tional safety }\end{array}$ & $\begin{array}{c}\text { Sales \& } \\
\text { recruitment }\end{array}$ & $\begin{array}{l}\text { Employee } \\
\text { training }\end{array}$ & $\begin{array}{l}\text { Workforce } \\
\text { education }\end{array}$ & $\begin{array}{c}\text { Process } \\
\text { optimization } \\
\text { simulation }\end{array}$ & $\begin{array}{l}\text { Nano/bio } \\
\text { tech design }\end{array}$ & $\begin{array}{l}\text { Command } \\
\& \text { control }\end{array}$ \\
\hline
\end{tabular}

The railway management games, such as "Railroad Tycoon" (1990-2003) and "Rails Across America" (2001) highlights the historical events, engineering and railway management economy, and have a very large impact on the players to gain a variety of skills and knowledge. The geographic games, such as "PlaceSpotting" (2008-2009) help the players to find certain areas of the planet through some indicators and tips. These games are used in educational sector, academic circles and so on.

Having the simulation effect of any action, the video games are very useful, since they do not create a threat. The US Air Force, of course, does not immediately send their pilots to fly the aircrafts, which cost millions of dollars. When training the pilots to drive the plane, they use aircraft simulators truck. These virtual simulators are designed for any mission, training and preparation in the real world and virtually warn about any damage or loss of life in the learning process. The pilot may experience the plane crash in the simulator, learn his/her mistakes, come to certain conclusions and operate more successfully by reloading the program. The process results in a higher level of activity in the simulator and the pilot starts to fly a real plane.

The games, such as SOCOM and Call of Duty are used in the military. The players earn tactical skills, trying to reach the goal in the virtual games. This allows the soldiers making the right decisions in specific situations. 
The strategy game Civilization V is incredibly popular among consumers. The players act as a founder and leader of cultures covering the period from ancient times to the century of space, trying to make strategic decisions on the expansion of diplomacy, economic development, technology, state-building and are military conquests in order to become a virtual "World leader". Civilization V has conquered the K-12 (a 12-year school education) market. The game teaches the students to compromise and come to concession in the military and cultural spheres and so on by presenting the historical content. Players are using the game as a model for projecting the historical and social systems in their imaginations.

EcoMUVE is an educational program and academic research project developed by Harvard University to teach the students the cause and effect patterns in the ecosystems through the use of simulators and modeling. Through the use of very interesting and useful video games, the students are acting as a water quality expert, naturalist, microscopic experts, investigators and etc. and examining the environmental issues both in a team, and individually, trying to make the best decisions [25].

The Russian preschool education institutions, secondary and higher schools are also using educational games at the learning process; moreover, the international conferences and competitions are held in this regard. The teachers, students, and pupils regularly benefit from the resources related to the educational games in the websites [26-27].

The number of such samples can be enlarged by the foreign experience. Abroad, as well as in Azerbaijan, most of the banks have been organizing the courses, training and competitions, such as "Create and improve your own business", "International accounting basis" and so on for the employees and customers for many years and using the educational games. Some facts about the personal and domestic experience are as follows:

The students of Zagatala regularly take trainings individually or as a team, and, participate in the competitions across the districts and country. In 2014, the students of this school were the winners of the intellectual games "Aghil Daryasi" and "I am an Azerbaijani" (first place), and the team of the students from Zagatala became the champion of "Brain Ring" intellectual game, in 2015. During the 2010/2011 academic year, the students of Zagatala branch of Azerbaijan Institute of Teachers and the schoolchildren took part in the Third International Olympiad of the Intellectual Games “Эрудиты Планеты” held in Russia represented by 4 teams (24 people). 4 of the winners of the regional round joined the final stage of the Olympiad held in Moscow in 29.09.11 via the Internet. As a result, 1 student and 1 schoolchild got the name of "The best participants" on the Internet.

Learners in Azerbaijan tend to use the interesting resources and interactive games related to the subjects, such as computer science, physics, geography and so on some native sites and blogs [29-30].

Since 2007, the Azerbaijani teachers of science, geography, biology, physics, chemistry and etc. have been using the "Green Pack" multimedia training sets, including the educational movies. The academic curriculum of the "Green Package" training set includes the implementations as the application of extraordinary materials and methods, establishment of responsible behavior and so on. In 2014, a new edition of the set was supported by IDEA funds and Sustainable Development Association [31].

There are also teachers using the games, such as "Remove trash", "Merry Farm" and others promote the environmental education, waste sorting, knowing hazardous waste for primary school children. The learners are also very interested in the interactive maps available on the Internet, "Know Azerbaijan" game.

"Info-ko" drive designed by the "Baku" publishing house in 2008/2009 academic year for primary classes in all subjects, including in mathematics, native language, drawing, singing and so on also attracted the attention of the students.

One of the pressing issues of the day is to develop the students' reading comprehension skills, and therefore, a number of projects are carried out at the state level in Azerbaijan. Preparation of different types of questions of the crossword, which is a type of intellectual games, and its use is one of the main issues. Trying to setup a crossword, the student studies the subject and prepares comparative, generalized and evaluative questions in accordance with the factual content, looks for and finds their answers, and 
ultimately understands and comprehends the content. Therefore, setting up and solving the crosswords is one of the most effective methods used internationally for the development of the students' ability of reading and comprehension. As one of the entertaining materials used in the course, the crosswords and rebus attract the attention of the students making the learning process colorful and provide the individual and group examination of the specific knowledge. Solution or preparation of crossword and rebus:

- Provides to analyze the given question, to choose course materials according to a specific question or riddle, and to revise the learned materials;

- develops visual, artistic and spatial thinking, logical judgments, memory, awareness, ability to concentrate, reading competence, and imagination;

- Teaches the interaction within the group, to be responsible for own work, and develops the independence;

- Develops the creative thinking related to the written speech of the learner, furthermore, improves his/her skills, awareness rate and vocabulary;

- Provides the understanding of the basic notions and terms of the subject, teaches the literate writing, checking the mastering rate, and provides the interdisciplinary integration;

- Rebus presents the terms in an interesting and unusual form, and improves the motivation;

- Preparation of the rebus is the creative work to learn the nature of students. It is possible to analyze how the student imagines according to the picture, and "to discover" his/her new qualities;

- Trains the memory, forms the flexible thinking, and improves the vocabulary skills;

- Forms the ability to finish the job begun;

- As the finished crosswords are used in other classes, the student's motivation for the creative labor increases;

- Increases a desire to learn the subject and theory, and to work with books. Thoroughly examining each student at every lesson, show and explain the gaps in his/her knowledge is very important for his/her future activities, otherwise, these gaps in this "chain" of knowledge can not be detected and eliminated. This is a very difficult task. Preparing and solving the crossword on one or more topics by the student may greatly contribute to reduce this problem. Students enthusiastically prepare interesting crosswords related to the vital skills at lesson or at home, even together with parents and grandparents.

For many years, foreign teachers have been using the crosswords as a game for the knowledge acquisition and the learners' intellectual development; while in medicine they have been used as a sedative means. According to statistical data and research, American scientists believe that crossword is one of the most simple and effective means to neutralize the stresses of the dynamic and turbulent modern world. They prove that solving the crossword mobilizes all the organs of the body to optimally work. The satisfaction after the resolution of a crossword is also very valuable. It is considered to be equal to at least 5 minutes of laugh and vitamin C [32].

Australian scientist P.Barlet believes that continuously solving the crossword can remove some problems related to the age. According to the professor, the physical exercises and intellectual games stimulate the formation of new neurons and prevent the development of many diseases. P.Barlet ensures that the long-distance running and crossword solving helps to maintain "the light of intelligence" even at the old ages. The scientist advises to solve crossword as a habit for the formation of new nerve cells [32].

The scope of the crossword is continuously expanding; and it is used for the verification of the professional qualities. In recent years, the crossword has been used for advertising.

The crossword solving and preparation are given special attention in the international practice and various activities are carried out in this field. International Puzzle Federation annually organizes the world championship. The most famous competition was held in the Czech Republic, Prague. So far, the United States became the champion for 14 times, Germany for 6 times, the Czech Republic for 3 times, and the Japanese team for once (fig). Russia and Ukraine also hold different crossword puzzle championships and tournaments [33]. 


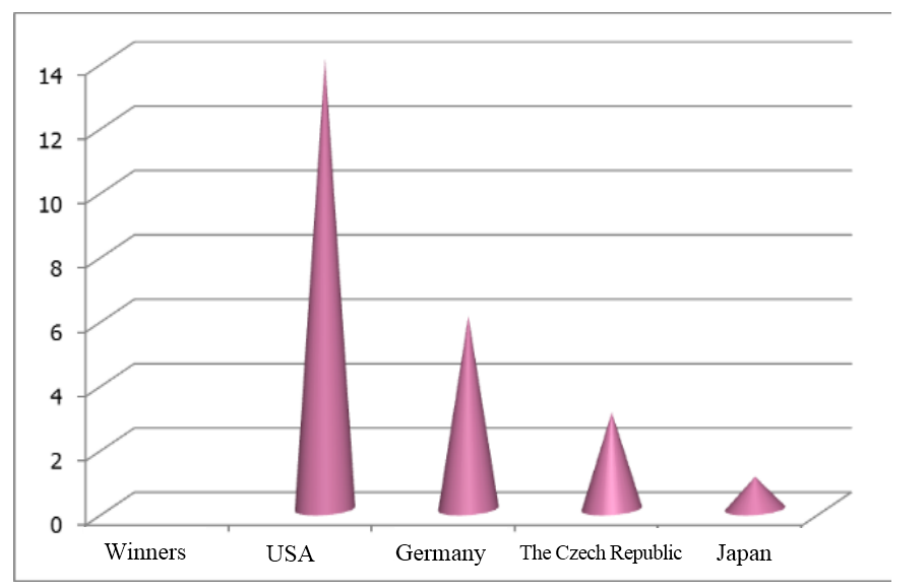

Fig. The number of crossword champions from different countries

In 2016, Azerbaijan Academy of Labor and Social Relations hosted the crossword competition within the framework of the "Crossword Competition" grant project by the Youth Foundation under the President of Azerbaijan Republic [34]. In this regard, the use of intellectual games at the lessons should be one of the most important issues of the day for the improvement of the knowledge of the learners and young people and for their participation in the international events.

\section{The application opportunities of intellectual games at computer science course}

Challenges faced in the process of teaching computer science are as follows:

- being more enthusiastic for games than the lesson, unsatisfactory motivation for learning, reading and understanding the theory, analysis and synthesis skills;

- the problems arisen from the assessment of each learner;

- using IT at schools mainly for entertainment;

- unsatisfactory use of intellectual and educational games,

- the lack of the classification of the intellectual games by various options and the lack of the games system set (polygraphic and computer version);

- poor ability of teachers to plan the game performance and to integrate it into the learning process, the lack of the technique to use the game technologies;

- the lack of methodical materials on educational games for different classes;

- the lack of various intellectual game-competitions regularly held at schools and etc.

The use of intellectual games in the process of lesson may affect overcoming these problems. Though the use of crossword and rebus has recently increased to a certain extent, this situation is not satisfactory yet. Depending on the subject, potential of the students and so forth, the following types of intellectual games can be regularly used at computer classes:

- intellectual games, tests;

- crossword, rebus;

- puzzles;

- anagrams;

- business game;

- quiz;

- lesson-game and so on.

The regular and proper use of different types of intellectual games in the learning process, as well as at the extracurricular and after-school activities, can effectively increase the learners' motivation, level of knowledge and solve problems associated to the assessment of knowledge and self-assessment. Based on the foreign experience, the use of intellectual games at the classroom, school, city (district) level, and holding competitions can have a tremendous impact of the scope of the students, as well as the growth of their various skills. 


\subsection{The algorithm for the integration of the educational and intellectual games into the learning process}

1. diagnostic examination of the knowledge and skills of the students on the subject through previously prepared tests, open-ended questions and crosswords (first at the beginning of the school year, and then at appropriate times);

2. dividing the students into three groups according to the result of the examination (poor, good, excellent);

3. preparing units according to the level of each group prepare a lesson and using them as homework. Using word-games at each lesson as much as possible (3-5 minutes).

\subsection{The algorithm for the school-based intellectual games:}

1. organizing competition-games and games-lesson in the process of teaching in every classroom and extracurricular actions, to lessons, and forming a team of intellectual students at each class;

2. holding training for the highest intellectual students at each class once a month;

3. organizing school-based intellectual game-competition in computer science among team consisting of the students of the III-IV, V-VI, VII-VIII, IX-X, X-XI classes each academic year.

\subsection{The algorithm for holding city intellectual games:}

1. forming teams of high intellectual students from different classes at each school;

2. organizing training-competition for the teams from each school once a month;

3. organizing intellectual game-competition in computer science among the schools and cities at the end of each academic year.

\section{Conclusion}

To take advantage of the IT addiction of the young for the educational purposes and to improve the quality of training, it is necessary to expand the research in this field and to organize the joint activities of IT professionals. The regular use of educational intellectual games and crosswords and the organization of customary competitions can effectively eliminate abovementioned problems, making the lessons more colorful, interesting, and providing the development of new terms related to the subject, increasing the motivation and intellectual level of the learners. The following activities could be the basis of successful implementation:

- classifying the educational intellectual games;

- regularly analyzing the intellectual level of the students in computer science, offering a method to track the progress, and developing curriculum;

- preparing the teaching methods and algorithm through the use of intellectual games taking into account the psychological and pedagogical aspects;

- exploring the ways to improve the acquisition of high-quality knowledge and expansion of free time for education and developing its application methodology;

- developing the ability of teachers to plan the game activity and to integrate it into the learning process, offering the methods for the use of game technologies;

- preparing various integrative intellectual games system (informative, practical, content inspection modules, e-learning resources)in the classroom and extracurricular activities;

- preparing "Entertaining Science" sample, including the crosswords for different classes and levels, furthermore, developing an electronic version and drive of the crossword samples using various programs;

- designing a web-site with an appropriate name (for example "The land of intellectual games" etc.), and uploading various intellectual games, the samples developed using different applications and the resources developed by teachers and students;

- organizing regular educational intellectual online competitions among the classes and 
schools, such as "Who is the most intelligent?", "Brain Ring" and so on.

\section{References}

1. Introduction to Using Games in Education: A Guide for Teachers and Parents. https://scholarsbank.uoregon.edu/xmlui/bitstream/handle/1794/3177/Games.pdf?sequence=1

2. Moral and Intellectual Development Through Play: How to Promote Children's. www.uni.edu/coe/regentsctr/publications/Moralandintellect.pdf

3. Moving learning games forward. Eric Klopfer, Scot Osterweil, and Katie Salen http://education.mit.edu/wp-content/ uploads/ 2015/01/ Moving Learning Games Forward_ EdArcade.pdf

4. Development through Playing Group Games by Rheta DeVries. www.uni.edu/coe/ regentsctr/publications/Moralandintellect.pdf

5. Mardanov M., Aghamaliyev R., Mehrabov A., Gardashov T. Monitoring and evaluation of the education system. Baku, Elm, 2010, 210 p.

6. https://ru.wikipedia.org/wiki/Интеллект

7. The Art of Computer Game Design by Chris Crawford. www.rohan.sdsu.edu/ stewart/cs583/ ACGD_ArtComputerGameDesign_ChrisCrawford_1982.pdf

8. Essential Facts About the Computer and Video Game Industry. www.theesa.com/wp-content/ uploads/2015/04/ESA-Essential-Facts-2015.pdf

9. A Literature Review of Serious Games for Intellectual Disabilities. http://link.springer.com/ chapter/ 10.1007\%2F978-3-319-24258-3_59\#page-1

10. https://en.wikipedia.org/wiki/Intellect

11. Runova O.B. Methods of investigating the intelligence, M .: Lan, 2006, 86 p.

12. Shatsky S.T. Fav. Ped. Op. In 2 volumes, volume 2, Moscow: Pedagogika, 1980, 416 p.

13. Ushinsky K.D. Collected Works, Volume 8, M.: Lan, 1950, 552 p.

14. Shiller I.F. Articles on aesthetics. M.: Lan, Academy, 1935, 674 p.

15. Great encyclopedic dictionary. Moscow, Scientific publishing house "The Great Russian Encyclopedia". St. Petersburg: "Norint", 2001. 434 p.

16. Groos K. The soulful life of a child. Kiev, 1916, 178 p.

17. Elkonin D.B. Psychology of the game. M: Lan, 1978, 314 p.

18. Stern V. Mental giftedness // Gifted child, 2002, No 3, 49 p.

19. Freud Z. I and It: Works. Moscow: ZAO Eksmo-Press; Kharkov: Publishing house "Folio", 1998, $1040 \mathrm{p}$.

20. Buhler Ch. Kindheit und Jugend. Leipzig, 1931, 508 p.

21. Ozhegov S.I., Shvedova N.Y. Explanatory dictionary of the Russian language, 4th ed., Ext., Moscow: Azbukovnik, 1999, 235 p.

22. https://itunes.apple.com/us/app/jeopardy!-americas-favorite/id377127117?mt=8

23. Isaenko V.P. Leader orientation in the activity of a specialist in socio-cultural activities: Monograph / MSUKI. Moscow, MSUKI, 2002, 148 p.

24. http://modpk7.narod.ru/index/0-7

25. Shmakov S.A., Games of students are the phenomenon of culture. Moscow: New School, 1994, 240 p.

26. http://institute-of-progressive-education-and-learning.org/elearning/elearning-educational-games/

27. www.igraemsa.ru/obuchajushhie-igry

28. www.science-education.ru/ru/article/view?id=1079

29. www.informatik.az

30. https://plus.google.com/104673147000009971153

31. www.greenpackonline.org/english/menu/html

32. www.e-crossword.ru/people/health/

33. www.indiana.edu/\%7Eintell/binet.shtml

34. www.news.lent.az/news/230395/ 